\title{
A STUDY OF COMPLIANCE POST-OFT INFRINGEMENT ACTION ${ }^{*}$
}

\section{A. INTRODUCTION}

The increasing level of fines being imposed on companies for involvement in anticompetitive activity in recent years, ${ }^{1}$ has ensured that compliance with competition law generally, and the interaction between OFT competition law enforcement and the development of corporate compliance strategies more specifically, are becoming increasingly significant. In this context, the OFT's role in advocating and promoting compliance with UK competition law is vitally important but was the subject of criticism by the National Audit Office in 2005:-

"The OFT surveys of business awareness of the competition regime have shown increasing awareness of competition legislation. Over half of the companies

\footnotetext{
* Professor Barry J Rodger, The Law School, University of Strathclyde, Glasgow, barry.j.rodger@strath.ac.uk. Many thanks to Dr Andreas Stephan, Norwich Law School and ESRC Centre for Competition Policy, UEA, and Dr Christine Parker, University of Melbourne, Australia for helpful comments on an earlier draft. Responsibility for the article and for any errors or omissions remain mine alone
}

1 See the OFT Register of decisions on its website at http://www.oft.gov.uk/advice_and_resources/resource base/ca98/decisions/accessed on 4 April 2008. On fines more generally, see C Veljanovski "Penalties for Price Fixers: An Analysis of Fines Imposed on 39 Cartels under EC Antitrust" [2006] European Competition Law Review 510 and "Cartel Fines in Europe" [2007] World Competition 65. 
surveyed, however, are still not aware of the laws and there is a clear relationship between awareness and size of company...The surveys also showed that awareness of the competition regime did not necessarily mean that companies understood their content. Nearly 40 per cent of respondents believed their knowledge of the legislation to be 'nothing'. This highlights a lack of understanding about competition matters, given that the interviews were conducted with the "person in the organization responsible for legal matters relating to trading practices."2

The background to the debate on compliance strategies is the dramatic reform of UK competition law brought about primarily by the Competition Act 1998, which introduced, as of 1 March 2000, two new prohibitions, (the Chapter I and Chapter II prohibitions). It also afforded significant investigative and fining powers to the UK competition authorities (primarily the OFT) for the first time. ${ }^{3}$ The radical change to a prohibition system with fines of up to $10 \%$ of world-wide turnover sought to enhance the deterrent effect of UK competition law, and since 1 March 2000 there has been a considerable body of practice developed by the OFT (and other regulators) and numerous fines

\footnotetext{
${ }^{2}$ National Audit Office, "The Office of Fair Trading - Enforcing Competition in Markets", report by the comptroller and auditor general, HC 593 Session 2005-2006, November 17, 2005. para.4.1.3 [available online at: www.nao.org.uk/pn/05-06/0506593.htm accessed on 5 April 2008]. See also G Murphy, "Auditor General Recommends the OFT Step it Up” [2006] European Competition Law Review 391.

${ }^{3}$ See B Rodger and A MacCulloch, (eds) The UK Competition Act: A New Era for UK Competition Law (Oxford, Hart Publishing, 2000); B Rodger, "The Impact of the Competition Act 1998: A New Competition Culture Emerges" (2002) 7 Scottish Law and Practice Quarterly 97.
} 
levied. ${ }^{4}$ Perhaps unsurprisingly, there was very little research prior to the 1998 Act in relation to business attitudes towards UK competition law. In 1992 Aaranson suggested that "business does not take competition policy adequately into account" and his experience was that companies did not plan rationally around the constraints it imposed. ${ }^{5}$ Frazer's subsequent empirical work, prior to the adoption of the 1998 Act, sought companies' views on certain propositions as to why they might comply, concluding that the purported deterrent effect of the potential imposition of fines was not clear-cut. ${ }^{6}$ Despite the new deterrence-based regime and the OFT's education initiative to enhance awareness and promote compliance, particularly in the period between the Act being passed and the prohibitions coming into force, very little empirical work has been undertaken on the relationship between enforcement and compliance in a UK context. ${ }^{7}$ In previous work, I undertook research into changes in compliance following the introduction of the Competition Act $1998,{ }^{8}$ and thereafter a more detailed study of three sample companies in the UK to assess the extent to which a compliance culture had

\footnotetext{
${ }^{4}$ See http://www.oft.gov.uk/advice_and_resources/resource base/ca98/decisions/accessed at 4 April 2008.

${ }^{5}$ A Aaranson, 'Do Companies Take any notice of Competition Policy' (1992) 2 Consumer Policy Review $140-145$.

${ }^{6}$ T Frazer, “Big Boys' Games, Big Boys' rules: Compliance, Competition Law and the Criminology of the Corporation' paper presented at Socio-Legal Studies association Annual Conference March 1995 and T Frazer, "Monopoly, Prohibition and Deterrence" (1995) 58 Modern Law Review 846.

${ }^{7}$ See, for instance, OFT, Competition Act Awareness Report, 2000, by Sample Surveys Ltd.

${ }^{8}$ Rodger, B "Compliance with Competition Law; A View from Industry" [2000] Commercial Liability Law Review 249.
} 
developed within those companies. ${ }^{9}$ More recently, the OFT commissioned a study into the deterrent effect of UK competition law enforcement, which noted inter alia that average consumer savings from Competition Act 1998 infringement decisions between 2004 and 2007 were $£ 64$ mill per year. ${ }^{10}$

Despite the limited work in a UK, and European, context, there has been fairly extensive research into competition law compliance in Australia. ${ }^{11}$ For over twenty years now the Australian Competition and Consumer Commission ('ACCC') has sought to become more strategic, particularly by focusing on 'nurturing compliance'. Dr Christine Parker

${ }^{9}$ B Rodger 'Competition Law Compliance Programmes: A Study of Motivations and Practice' (2005) World Competition 349.

${ }^{10}$ The deterrent effect of Competition enforcement by the OFT, A report prepared for the OFT by Deloitte, November 2007, OFT 962 at para. 2.5.

${ }^{11}$ Dr Christine Parker has been at the forefront of a number of research initiatives in this area. For instance, in 1999 she focused on the question how companies and regulators will be able to determine whether a compliance programme is effective;- C Parker, "Evaluating Regulatory Compliance: Standards and Best Practice" (1999) 7 The Trade Practices Journal 62. See also "Compliance professionalism and regulatory community: The Australian trade practices regime" (1999) 26 Journal of Law \& Society 215; C Parker and Connolly, "Is there a duty to implement a corporate compliance system in Australian law?" (2002) 30(4) Australian Business Law Review 275; C Parker, "Regulator-required corporate compliance program audits" (2003) 25 Law and Policy 221; see also C Parker The Open Corporation, (Cambridge University Press, Cambridge, 2003).

In this context, Parker's most recent work is also notable. As part of the Centre for Competition and Consumer Policy, a detailed project has been undertaken on compliance and enforcement with competition law in Australia: - see Parker and Stepanenko, Compliance and Enforcement Project: Preliminary Research Report, 2003, Centre for Competition and Consumer Policy, Australian National University, Canberra, http://www.cccp.anu.edu.au/projects/project1.html accessed at 5 April 2008. 
has been particularly prominent in developing a body of academic work focusing on ACCC encouragement of compliance-oriented enforcement strategies under the Trade Practices Act and empirically testing the extent to which Australian business have implemented effective compliance programmes. ${ }^{12}$ This Enforcement and Compliance Survey involved lengthy questionnaires being forwarded to the largest 2321 Australian businesses trading in 2004 in relation to their compliance programmes, practices and attitudes to enforcement by the ACCC under the TPA. ${ }^{13}$ One of the principal findings of the Australian compliance study was that commitment to compliance was demonstrably greater where a business had already been the subject of TPA enforcement action by the ACCC.

Following those findings from the Australian compliance study, it was decided to focus on companies which had already been subject to infringement action under the Competition Act 1998. The aim of the research was to ascertain commitment to compliance by companies in the UK post-infringement involving their awareness of

${ }^{12}$ ACCC Enforcement and Compliance Survey: Report of Preliminary Findings, December 2005, Dr V L Nielsen. and Dr C Parker.

${ }^{13}$ C Parker, C and V L Nielsen, "Do Businesses Take Compliance Systems Seriously?: An Empirical Study of the Implementation of Trade Practices Compliance Systems in Australia" (2006) 30 Melbourne University Law Review 441; C Parker, and V L Nielsen, "What do Australian Businesses Really Think of the ACCC, and Does it Matter?" (2007) 34 Federal Law Review 1; C Parker and V L Nielsen, "How Much Does it Hurt? How Australian Businesses Think about the Costs and Gains of Compliance with the Trade Practices Act” Melbourne Law School Legal Studies Research paper no 310, ssrn.com/abstract=1085054, accessed on 5 April 2008; C Parker, and V L Nielsen, “To What Extent do Third Parties Influence Business Compliance' forthcoming. Hereinafter, this work shall be referred to collectively as the 'Australian compliance study'. 
competition law, their attitude to competition law and authorities, the impact of enforcement on their organization, the extent to which elements of a formal compliance programme had been adopted, and how they perceived the range of costs and gains of compliance and non-compliance. The research sought to ascertain levels of compliance commitment in this defined business group where one would have expected greater awareness and a more coherent approach to compliance. It would also allow us to reflect on the OFT's competition law enforcement strategies and to make some tentative comparisons with the outcomes of the Australian compliance study on similar themes and issues associated with compliance. ${ }^{14}$ Accordingly, the questionnaire utilized was modeled, in terms of structure and the content of particular questions, on the Australian compliance survey questionnaire in order to allow for comparability. The article will first outline the Australian compliance study and then proceed to discuss the research methodology, response rate and the principal findings of the current study on the various aspects of the questionnaire outlined above, before drawing conclusions in relation to the compliance practice of the respondents and the implications for an appropriate education strategy by the OFT to further encourage and facilitate compliance behaviour.

\section{B. THE AUSTRALIAN COMPLIANCE STUDY}

\footnotetext{
${ }^{14}$ This paper will not tackle the more problematic issue of the relationship between corporate liability and internal compliance mechanisms. See for instance, W S Laufer, "Corporate Liability, Risk Shifting, and the Paradox of Compliance" (1999) 52 Vanderbilt Law Review 1343; K D Krawiec, "Organizational Misconduct: Beyond the Principal-Agent Model” 32 Florida State University Law Review 571; J Hill, "Corporate Criminal liability in Australia: An Evolving Corporate Governance Technique" [2003] Journal of Business Law 1.
} 
Following the research undertaken in the Australian compliance survey, Parker and Nielsen have considered various aspects of the multi-faceted research outcomes. ${ }^{15}$ In doing so, they emphasised the role of the ACCC in using its

"enforcement, as well as its educative and liaison activities, to encourage the adoption of compliance systems. In doing so, the ACCC hopes to garner both deeper and wider business commitment to, and achievement of, competition and consumer protection goals that it can accomplish through litigation alone."16

The ACCC has sought to nurture compliance professionalism and adopt strategies to encourage greater and wider adoption and implementation of compliance systems involving a wide range of key elements, inter alia, the adoption of a compliance policy, the appointment of a compliance officer or dedicated compliance unit, a complaints handling system, frequent training of staff and regular reviews of the system's effectiveness. ${ }^{17}$ Parker and Nielsen assessed the extent to which businesses adopted a number of key compliance elements, which were divided into four groups: complaints handling; communication and training; management and accountability and whistleblowing; and performance measurement and discipline. Generally, the results suggested that 'implementation of trade practices compliance systems is partial, symbolic

\footnotetext{
${ }^{15}$ See supra $\mathrm{n} 13$.

${ }^{16}$ C Parker, and V L Nielsen, “Do Businesses Take Compliance Systems Seriously?: An Empirical Study of the Implementation of Trade Practices Compliance Systems in Australia" (2006) 30 Melbourne University Law Review 441, 445.

${ }^{17}$ Ibid $450-455$.
} 
and half-hearted ${ }^{18}$ but that ACCC enforcement action improved compliance system implementation across each of the groups. ${ }^{19}$ On this basis, one would anticipate that the results in terms of compliance system implementation, considering similar elements across the four main group headings, would be more favourable in the context of research targeted at business which had already been the subject of competition enforcement action in the UK.

As noted earlier, various aspects of the research are modelled on the Australian study, and one important issue is business perceptions of the competition authority's role and its impact on how those businesses engage with and interact with the law. ${ }^{20}$ This is crucial in developing a compliance-oriented approach, which is not simply predicated on assessing enforcement strategies and the outcome of authority enforcement actions but seeks to understand how and why businesses comply or do not comply with the law, and how this may be facilitated. ${ }^{21}$ Parker and Nielsen argue that the three main theories which seek to explain compliance behaviour are: - 1) deterrence theory, based on rational and calculated decisions by actors; ${ }^{22}$ 2) compliance based on a 'normative commitment' to

${ }^{18}$ Ibid, 444. See also K Krawiec, "Cosmetic Compliance and the Failure of Negotiated Governance" (2003) 81 Washington University Law Quarterly 487 and the concern with 'cosmetic compliance'.

${ }^{19}$ Parker and Nielsen, supra n 16, 476.

${ }^{20}$ C Parker, C and V L Nielsen, "What do Australian Businesses Really Think of the ACCC, and Does it Matter?" (2007) 34 Federal Law Review 1.

${ }^{21}$ Ibid, 4.

${ }^{22}$ See S Simpson, Corporate Crime, Law and Social Control (Cambridge, Cambridge University Press, 2002) 22-44 for a fuller discussion of this issue including, at 41 , the critique of the limits of rationality in this context, indicating that compliance is more likely to be affected by a party's 'perceptual deterrence', a more appropriate subjective test. 
the legitimacy of the legal rules; and 3) the important of the social influence exerted by peer and third party groups to comply or not with particular legal rules. ${ }^{23}$ Accordingly, potentially there are pluralistic motivations for compliance with legal rules, ${ }^{24}$ which would support the responsive regulation model developed primarily by Braithewaite. ${ }^{25}$

The current research considers the extent to which a range of motivating factors are relevant to respondents' compliance decisions and relates these broadly to those three main theories. More specifically, we will look closely at business perceptions as to the costs and gains of compliance and non-compliance with the Competition Act. ${ }^{26}$ In this context, classical deterrence theory is based on rational calculations about potential gains and losses associated with a breach of the law. ${ }^{27}$ However, Parker and Nielsen, in a related paper on costs and gains in relation to the Australian compliance study, ${ }^{28}$ stressed the limitations on apparently rational, objective calculation and noted a more recent

${ }^{23}$ See S Winter, and P May, "Motivation for Compliance with Environmental Regulations" (2001) 20 Journal of Policy Analysis and Management 675, 678.

${ }^{24}$ See Winter and May ibid, regarding their threefold typology of compliance motivating factors: 'calculative', 'normative' and 'social'.

${ }^{25}$ See J Braithwaite, Restorative Justice and Responsive Regulation (New York/Oxford, OUP, 2002); I Ayres, and J Braithwaite, Responsive Regulation: Transcending the Deregulation Debate, (New York/Oxford, OUP, 1992)

${ }^{26}$ C Parker, and V L Nielsen, "How Much Does it Hurt? How Australian Businesses Think about the Costs and Gains of Compliance with the Trade Practices Act" Melbourne Law School Legal Studies Research paper no 310, ssrn.com/abstract=1085054 accessed on 5 April 2008.

${ }^{27}$ See, for example, J Scholz, "Enforcement Policy and Corporate Misconduct: The Changing Perspectives of Deterrence Theory" (1997) 60 Law and Contemporary Problems 253.

${ }^{28}$ Parker and Nielsen, supra, n 26. 
emphasis in the field on 'perceptual deterrence'. ${ }^{29}$ Accordingly, when the focus shifts from the strategy of regulatory enforcement to understanding compliance and business perceptions of risk, a broader awareness of the factors which may actually drive compliance decisions is required than simply considering formal sanctions. ${ }^{30}$ Moreover, it can be argued that the concept of deterrence extends to the consideration to the various informal social and economic sanctions that can inform, generate and influence business compliance. $^{31}$ This was a particularly important strand in the Australian compliance study and Nielsen and Parker note, in a further paper, that

"one of the main policy messages of the current literature on regulatory compliance is that there is likely to be a higher rate of business compliance with the law when a plurality of actors (public and private) utilise their plural resources and relationships with regulatees to activate the plurality of motivations for compliance than when regulatory agencies rely on official powers alone."32

Therefore, third parties, notably social and economic stakeholders, may play an important role in developing a compliance culture by playing on a combination of businesses'

\footnotetext{
${ }^{29} \mathrm{Ibid}, 16$

${ }^{30} \mathrm{Ibid}, 19$.

${ }^{31}$ Ibid, 13. See also for example, J Braithwaite, Crime Shame and Reintegration (Cambridge/New York, Cambridge University Press, 1988) 71-75.

${ }^{32}$ C Parker, and V L Nielsen, "To What Extent do Third Parties Influence Business Compliance' forthcoming at 3 .
} 
calculative, social and normative motivations to comply, ${ }^{33}$ and we sought to ascertain any such influence in the current study.

\section{THE COMPLIANCE RESEARCH STUDY}

\section{Methodology}

The research was commenced in Summer 2006 and a database of all infringement decisions under the Competition Act 1998 between 1 March 2000 and the end of 2005 was compiled, ${ }^{34}$ including details of all parties which were the subject of infringement decisions, given the focus of the research on parties subject to enforcement action. This included the party deemed to be in infringement of the Chapter II prohibition by the CAT in Burgess $v$ OFT, ${ }^{35}$ which overruled the earlier OFT decision that there had been no infringement. This was a census-based research in which questionnaires were forwarded to all infringing parties within the relevant period, addressed to either the company secretary or the managing director in the first instance. ${ }^{36}$ The questionnaires were modelled on parts of the Australian compliance survey questionnaire, and contained a

${ }^{33}$ S Winter, and P May, "Motivation for compliance with environmental regulations" (2001) 20 Journal of Policy Analysis and Management 675 regarding the tripartite categorisation of calculative, social and normative motivations. See also N Gunningham, R A Kagan, and D Thornton, Shades of Green: Business, Regulation and Environment (Stanford University Press, 2003) 35-38, where they categorise different business 'stakeholders' into three groups: 'economic stakeholders' 'legal or regulatory stakeholders' and 'social stakeholders'.

${ }^{34}$ This extended to 17 Chapter 1 infringement decisions and 5 Chapter 2 infringement decisions.

${ }^{35}$ [2005] CAT 25, 6 July 2005.

${ }^{36}$ It should be noted that some parties appeared in relation to more than one infringement, but they were only forwarded one questionnaire. 
range of questions within the following main sections, with scope also for further comments: - your organisation, the Competition Act 1998 and the OFT; your organisation's knowledge of the 1998 Act; the impact of the Act on your Organisation; and the costs and benefits of complying with the Act. ${ }^{37}$ This is the order in which the results will be discussed in the article.

\section{Response Rate}

Questionnaires were mailed to 81 organisations which had breached either Competition Act prohibition during the relevant period. In total, 20 completed questionnaires were returned over a period of 10 months between 24 August 2006 and 22 June 2007. During this period there was considerable follow-up correspondence, calls and e-mails to all relevant organizations. Of the other 61 organisations, 48 simply refused to answer the questionnaire. The remaining 13 organizations could not be contacted or had gone out of business and were accordingly excluded when calculating the response rate which is $33 \%{ }^{38}$ It should also be noted that questionnaires were entitled Chapter 1 or Chapter II prohibition when forwarded as appropriate to the relevant organizations and all 20 responses were by parties which had infringed the Chapter I prohibition. The response rate of $33 \%$ is reasonable, if slightly lower than similar management focused

\footnotetext{
${ }^{37}$ It should of course be noted that the respondents compliance activity may not simply be based on UK competition law and OFT enforcement activity, but may also be influenced by the impact of EC competition law and DG Comp enforcement action, although it would be difficult to distil the effects of these two complementary systems, and the current research does not seek to do so.

${ }^{38}$ Questionnaires could not be delivered in 9 cases and 4 organisations had been taken over or had gone into liquidation/administration.
} 
questionnaire-based studies, ${ }^{39}$ and notably the Australian study response rate was $43 \%,{ }^{40}$ although the general difficulties in persuading senior management to respond to questionnaires in recent years has been regularly commented upon. ${ }^{41}$ The response rate is considerably higher than the $9.5 \%$ response rate for the other major competition law compliance study in the UK in $2000 .^{42}$ Furthermore, given the anticipated difficulties in securing responses from organizations to a survey about their own illegal conduct

39 See for instance, M A McKendall, and J A Wagner, "Motive, Opportunity, Choice, and Corporate Illegality" (1997) 8 Organization Science 624 where a response rate of 34\% was obtained in relation to surveys sent to two different management targets within the largest $1000 \mathrm{US}$ corporations; J Batten, S Hettihewa and R Mellor, "The Ethical Management Practices of Australian Firms” (1997) 16 Journal of Business Ethics 16: 1261, involving a 27.6\% response rate in a study into Australian business and ethical management practices; and G R Weaver, T K Trevino, and P L Cochran, "Corporate Ethics Practices in the Mid-1990's: An Empirical Study of the Fortune 1000” (1999) 18 Journal of Business Ethics 283 which resulted in a response rate of $26 \%$.

${ }^{40}$ There were considerable time and resources devoted to this project, with an average of 29 phone calls per completed questionnaire and many additional e-mails and postal contacts.

${ }^{41}$ N Gunningham, R A Kagan and D Thornton, "Social License and Environmental Protection: Why Businesses Go Beyond Compliance” (2004) 29 Law \& Social Inquiry 307; J Goyder and J McK Leiper, "The Decline in Survey Response: A Social Values Interpretation" and J J Hox and E D de Leeuw, "A Comparison of Non-Response in Mail, Telephone and Face-to-Face Surveys" in D De Vaus (ed.), Social Surveys (London, Sage Publications, 2002) 191-210 and 157-171 respectively; T V Greer, N Chuchinprakarn, and S Seshadri, "Likelihood of Participating in Mail Survey Research: Business Respondents' Perspectives" (2000) 29 Industrial Marketing Management 97. M Useem, "Reaching Corporate Executives", in R Hertz and J B Imber (eds.), Studying Corporate Elites Using Qualitative Methods (Thousand Oaks, Sage Publications, 1995) 18-39.

${ }^{42}$ See Rodger supra, n 9. 
focusing on how and why organizations had not complied with the law and how this position may or may not have changed subsequently, $33 \%$ is a reasonably satisfactory response rate. Nonetheless, we are dealing with results from a very small number of completed questionnaires, 20 in total, and the study is not intended to be scientific or give any accurate representation of compliance behaviour by UK industry generally, but merely provides indications of the experience and attitudes of a limited sub-group of UK businesses. As indicated, the research only focused on companies subject to UK infringement action in the relevant period, on the basis of the hypotheses that they would have the greatest compliance commitment. ${ }^{43}$ The questionnaires requested information about the individuals completing the questionnaire and this generally demonstrated their experienced background within the relevant organization, with the respondents including 9 managing directors, 1 Chairman, 6 directors, 1 secretary, 1 general counsel, a manager and a director. All had worked for more than 1.5 years within the relevant organisation, only 2 had worked for less than 8 years and the mean was 19.1 years experience within the organization. The mean period for respondents in their present formal position within the organization was 10 years (9.99), with only two being in that position for under two years. Accordingly, the individual respondents generally had a clear appreciation of the background to their organisation's efforts at competition law compliance and the impact of the infringement decision on compliance management in practice, although it should

\footnotetext{
${ }^{43}$ Accordingly, we did not utilise a control sample of matched businesses which had not been subject to enforcement action. Furthermore, it would have been impossible, in an anonymous survey, to ensure appropriate identification and matching as between responses from the two different sets of organisations.
} 
be stressed that one should be cautious about over-reliance on self-report data in relation to compliance activity.

3. The Research Outcomes

(a) Your Organisation, the Act and the OFT I-Views on Competition

Table 1

\begin{tabular}{|l|l|l|l|l|l|l|}
\hline $\begin{array}{l}\text { Views on } \\
\text { Impact of:- }\end{array}$ & $\begin{array}{l}\text { Very } \\
\text { damaging }\end{array}$ & Damaging & Neither & Beneficial & $\begin{array}{l}\text { Very } \\
\text { Beneficial }\end{array}$ & $\begin{array}{l}\text { Scale } \\
(1-5)\end{array}$ \\
\hline $\begin{array}{l}\text { Agreements } \\
\text { to fix prices }\end{array}$ & 25 & 35 & 35 & 5 & 0 & 2.4 \\
\hline $\begin{array}{l}\text { Agreements } \\
\text { to share } \\
\text { markets }\end{array}$ & 20 & 25 & 30 & 25 & 0 & 2.6 \\
\hline $\begin{array}{l}\text { Abuse of } \\
\text { dominance }\end{array}$ & 45 & 40 & 15 & 0 & 0 & 1.7 \\
\hline
\end{tabular}

Table 1 details the respondents' answers concerning the extent to which various practices were damaging or beneficial to UK economic well-being to assess their attitude to particular types of anti-competitive behaviour. As throughout, the responses are noted as percentages and the mean answer to the responses is noted on the basis of the scale 1-5, from very damaging (1) to very beneficial (5). Under the Australian compliance study, $87 \%$ and $78 \%$ agreed that price-fixing and market sharing respectively were damaging or very damaging, compared to the figures of $60 \%$ and $45 \%$ obtained in this study. Interestingly, all questionnaires were returned by parties which had breached the Chapter I prohibition, (which deals with anti-competitive agreements such as price-fixing and market sharing), and $85 \%$ of respondents considered abuse of dominance (dealt with by the Chapter II prohibition) to be damaging or very damaging, despite the general 
consensus that cartel activity (particularly price-fixing) is the most heinous anticompetitive behaviour. $^{44}$

Table 2

\begin{tabular}{|l|l|l|l|l|l|l|l|}
\hline Views on: & $\begin{array}{l}\text { Strongly } \\
\text { disagree }\end{array}$ & Disagree & Neither & Agree & $\begin{array}{l}\text { Strongly } \\
\text { agree }\end{array}$ & $\begin{array}{l}\text { Don't } \\
\text { Know }\end{array}$ & $\begin{array}{l}\text { Scale } \\
(1-5)\end{array}$ \\
\hline $\begin{array}{l}\text { Competition } \\
\text { Act has Clear } \\
\text { Goals }\end{array}$ & 5 & 30 & 5 & 45 & 10 & 5 & $\begin{array}{l}3.26 \\
(3.78)\end{array}$ \\
\hline $\begin{array}{l}\text { Most Managers } \\
\text { ashamed if } \\
\text { caught } \\
\text { Breaching Act }\end{array}$ & 5 & 20 & 15 & 40 & 20 & 0 & 3.5 \\
\hline $\begin{array}{l}\text { Most Managers } \\
\text { ashamed if } \\
\text { committed } \\
\text { Breaching Act }\end{array}$ & 5 & 15 & 15 & 50 & 15 & 0 & $(4.07)$ \\
\hline
\end{tabular}

Table 2 details the respondents' answers to three questions concerning attitudes to the Competition Act and its breach by the company. The mean answer to the responses is noted on the basis of the scale $1-5$, from strongly disagree (1) to strongly agree (5), ${ }^{45}$ and as throughout, where available, the equivalent result from the Australian compliance study will be included in brackets for comparative purposes. ${ }^{46} 55 \%$ agreed or agreed strongly that the Act has clear goals, whereas the figure for the Australian compliance

${ }^{44}$ Referred to as "The supreme evil of antitrust" by Justice Scalia, Justice of the US Supreme Court in Verizon Communications Inc v. Law Offices of Curtis v Trinko LLP 540 US (2004) 8.

${ }^{45}$ The mean for the first issue in Table 2 was calculated on the basis of 19 responses as there was one 'Don't Know' response which could not be placed on the scale.

${ }^{46}$ As noted above, it should be stressed that the results for the Australian compliance study includes all respondents, not simply those from infringing businesses. Nonetheless, the figures are lower in the current study, restricted to businesses which have infringed UK competition law, in respect of virtually all issues which would demonstrate a positive attitude and commitment to compliance. 
study in relation to the goals of the TPA was $77 \%{ }^{47}$ Similarly, although $60 \%$ and $65 \%$ agreed or agreed strongly that most managers would be ashamed if they were caught/committed a breach of the Act, the figures for Australia were considerably higher at $95 \%$ and $86 \%$ respectively. ${ }^{48}$

(b) Your Organisation, the Act and the OFT II- OFT Enforcement Action

Table 3

\begin{tabular}{|c|c|c|c|c|c|c|c|}
\hline Views on: & $\begin{array}{l}\text { Strongly } \\
\text { disagree }\end{array}$ & Disagree & Neither & Agree & $\begin{array}{l}\text { Strongly } \\
\text { Agree }\end{array}$ & $\begin{array}{l}\text { Don't } \\
\text { Know }\end{array}$ & $\begin{array}{l}\text { Scale } \\
(1-5)\end{array}$ \\
\hline $\begin{array}{l}\text { Breach Act- } \\
\text { Chances being } \\
\text { Caught Slight }\end{array}$ & 10 & 60 & 10 & 15 & 5 & $\mathbf{0}$ & 2.45 \\
\hline $\begin{array}{l}\text { Breach Act- } \\
\text { Enforcement by } \\
\text { OFT Slight }\end{array}$ & 35 & 40 & 10 & 15 & $\mathbf{0}$ & $\mathbf{0}$ & $\begin{array}{l}2.2 \\
(3.77)\end{array}$ \\
\hline $\begin{array}{l}\text { OFT wide range } \\
\text { of } \quad \text { effective } \\
\text { sanctions }\end{array}$ & 5 & 15 & 5 & 40 & 45 & $\mathbf{0}$ & $\begin{array}{l}3.85 \\
(3.65)\end{array}$ \\
\hline $\begin{array}{l}\text { Hard for OFT to } \\
\text { uncover } \\
\text { breaches }\end{array}$ & $\mathbf{0}$ & 30 & 20 & 35 & 5 & 10 & $\begin{array}{l}3.17 \\
(3.65)\end{array}$ \\
\hline $\begin{array}{l}\text { Complexity of } \\
\text { Tasks- OFT has } \\
\text { few resources }\end{array}$ & 10 & 35 & 30 & 10 & 15 & $\mathbf{0}$ & $\begin{array}{l}2.94 \\
(2.82)\end{array}$ \\
\hline $\begin{array}{lr}\text { OFT } & \text { Staff } \\
\text { competent } & \\
\text { compared } & \text { to } \\
\text { company } & \\
\text { lawyers } & \\
\end{array}$ & 15 & 30 & 30 & 10 & 5 & 10 & $\begin{array}{l}2.56 \\
(2.89)\end{array}$ \\
\hline $\begin{array}{l}\text { OFT Keeping a } \\
\text { close eye on our } \\
\text { Industry }\end{array}$ & 5 & 10 & 15 & 35 & 25 & 10 & $\begin{array}{l}3.72 \\
(3.23)\end{array}$ \\
\hline $\begin{array}{l}\text { Breach Severe } \\
\text { before OFT Acts }\end{array}$ & 30 & 50 & 15 & $\mathbf{0}$ & $\mathbf{0}$ & 5 & 1.84 \\
\hline
\end{tabular}

${ }^{47}$ See Nielsen and Parker, 2005 Report, supra n 20, 92.

${ }^{48}$ C Parker and V L Nielsen, "Do Businesses Take Compliance Systems Seriously?: An Empirical Study of the Implementation of Trade Practices Compliance Systems in Australia" (2006) 30 Melbourne University Law Review 441 at 487. 


\begin{tabular}{|l|l|l|l|l|l|l|l|}
\hline $\begin{array}{l}\text { Level of } \\
\text { Sanctions for } \\
\text { Breach } \\
\text { generally v low }\end{array}$ & 40 & 40 & 15 & 5 & 0 & 0 & 1.85 \\
\hline
\end{tabular}

Table 3 details the respondents' answers to a number of questions concerning what Parker and Nielsen have called 'the barometer of regulatory threat'. ${ }^{49}$ The relatively high figure of $70 \%$ disagreement with the proposition that the chances of being caught are slight must reflect to some extent the focus of this study on post-infringement compliance which makes it difficult to draw any general conclusions or any direct comparisons with the Australian compliance study involving a much larger sample with non-infringing businesses. Nonetheless, the figures for the final three issues are also notable, with a majority of respondents, $60 \%$, in agreement that the OFT is keeping a close eye on our industry and a preponderance of respondents, $80 \%$, disagreeing that the breach must be severe before the OFT acts and that the level of sanctions for breach is generally very low, although this may reflect the post-infringement context of the respondents in this study. Parker and Nielsen have similarly noted in relation to the Australian compliance study, that it is not surprising that those 'who have interacted with the ACCC ....have a higher view of the likelihood and severity of enforcement action. ${ }^{50}$

\footnotetext{
${ }^{49}$ See Nielsen and Parker, Report of Preliminary Findings, December 2005, Chapter 6. It should be noted that the mean from the Australian compliance study has been omitted in certain answers where the questions were reversed. See Parker and Nielsen, supra n 20,13-14. In addition, some of the mean figures in the current study were calculated on the basis of the responses excluding those which selected 'don't know'.

${ }^{50}$ Parker and Nielsen, supra $\mathrm{n} 20,30$.
} 


\section{(c) Self-estimated levels of compliance}

We asked respondents to assess their organisation's culture of compliance ${ }^{51}$ and actual compliance during the years 2000-2006 inclusive. We provided a scale of 1-100 for each year and asked respondents to mark appropriately, with 100 denoting that the culture or actual levels of compliance were very high. Graphs 1-4 provide details of the responses for 2000 and 2006 respectively in each category.

\section{Graph 1}

\footnotetext{
${ }^{51}$ By culture of compliance we noted that this meant 'attitudes and systems that support compliance with the Competition Act 1998'.
} 


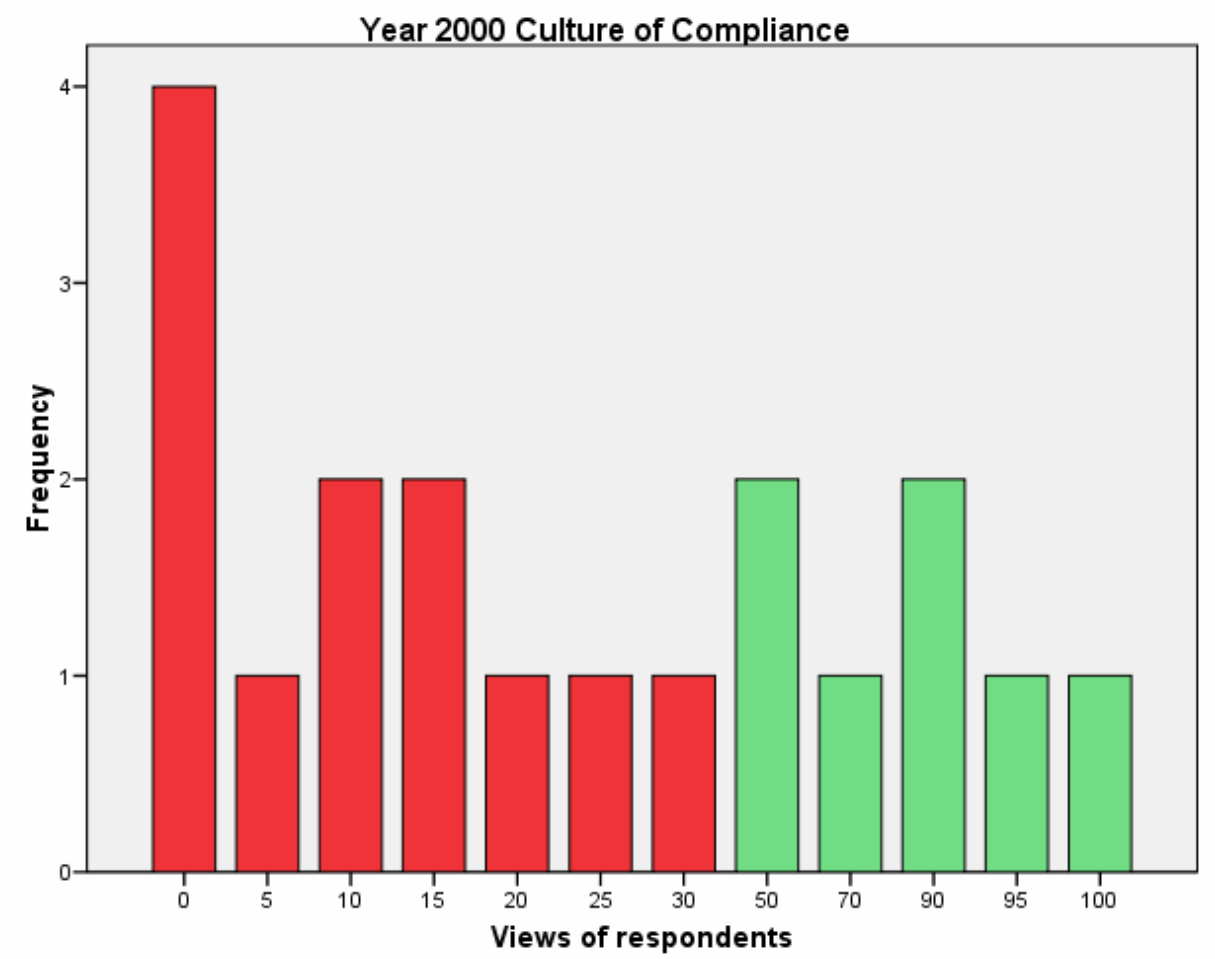

\section{Graph 2}

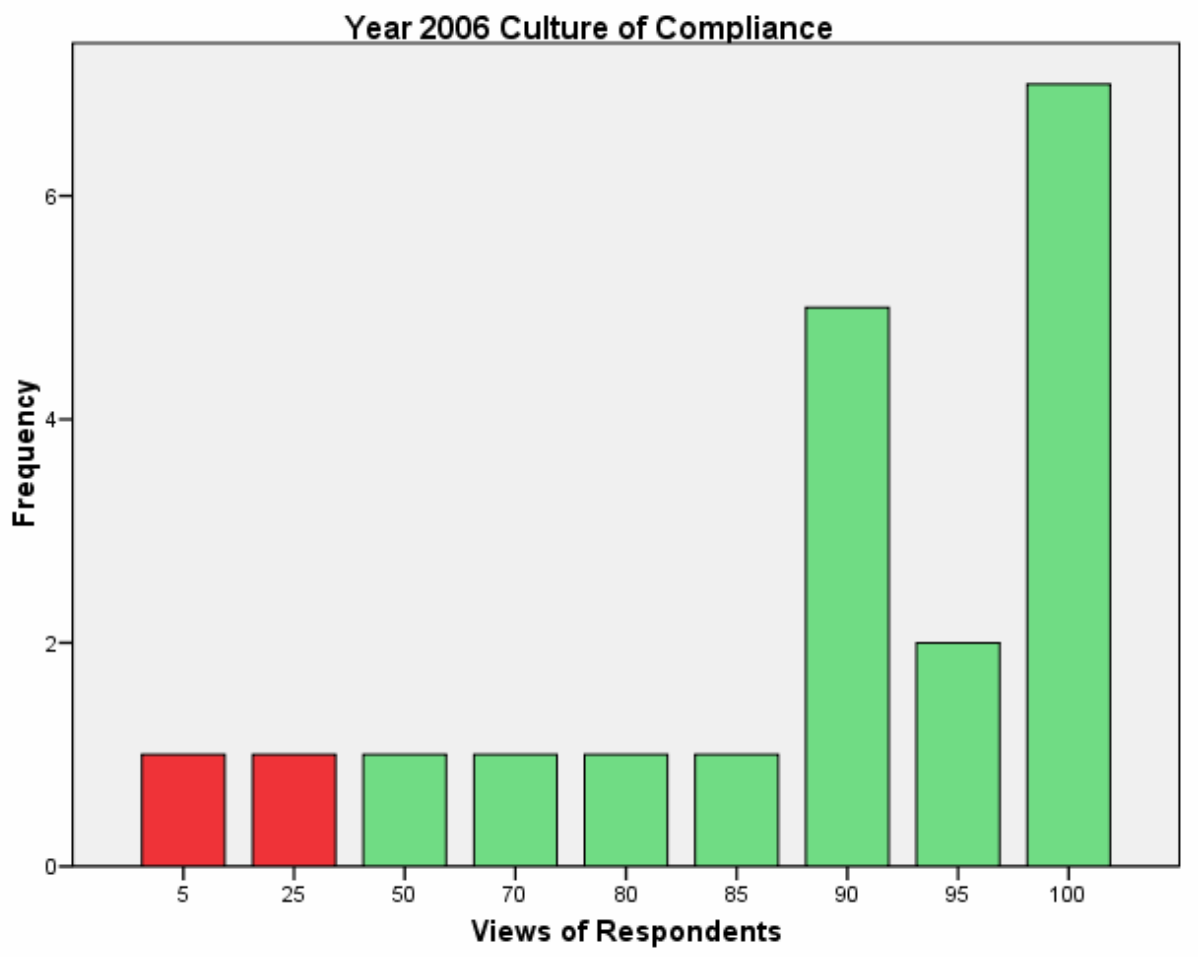




\section{Graph 3}

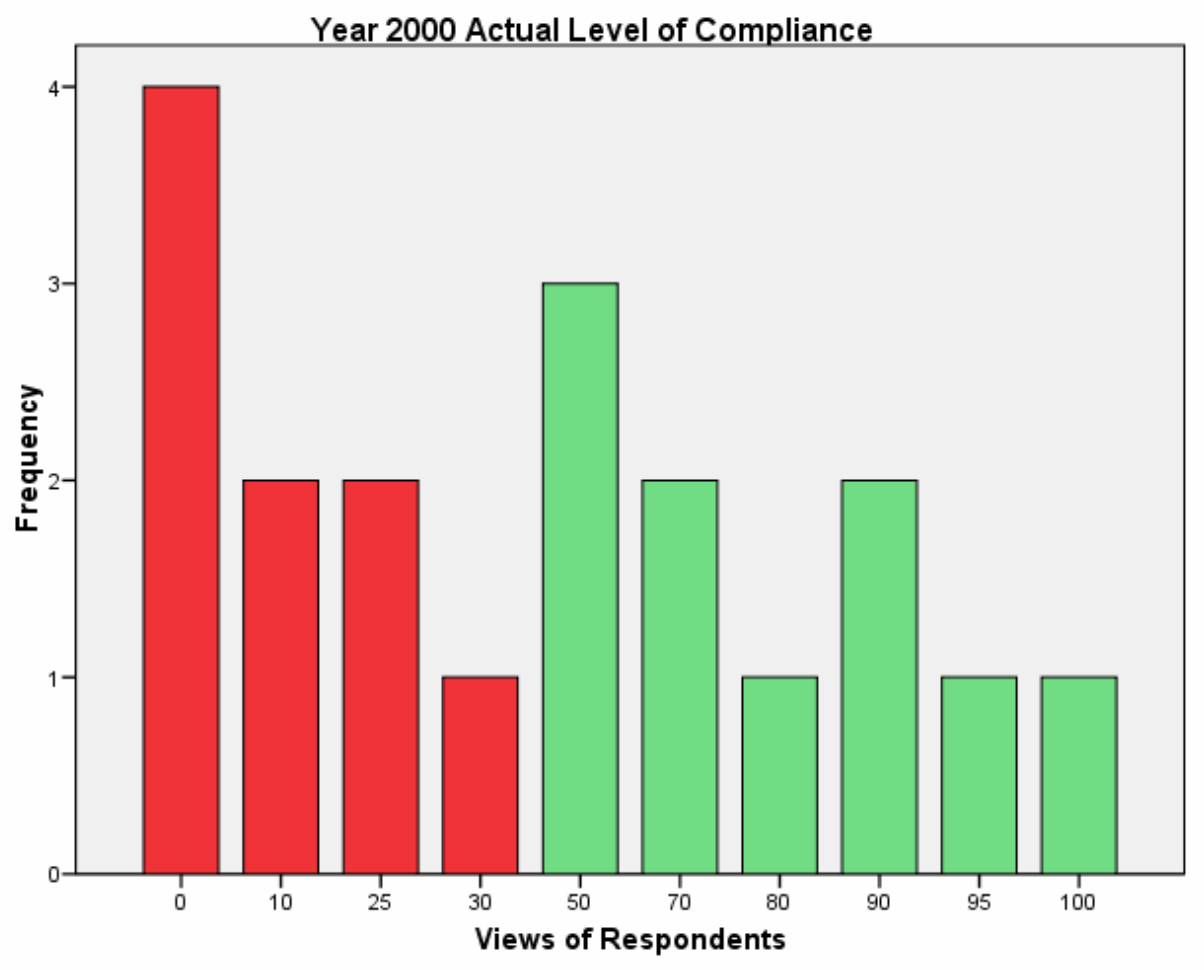

\section{Graph 4}

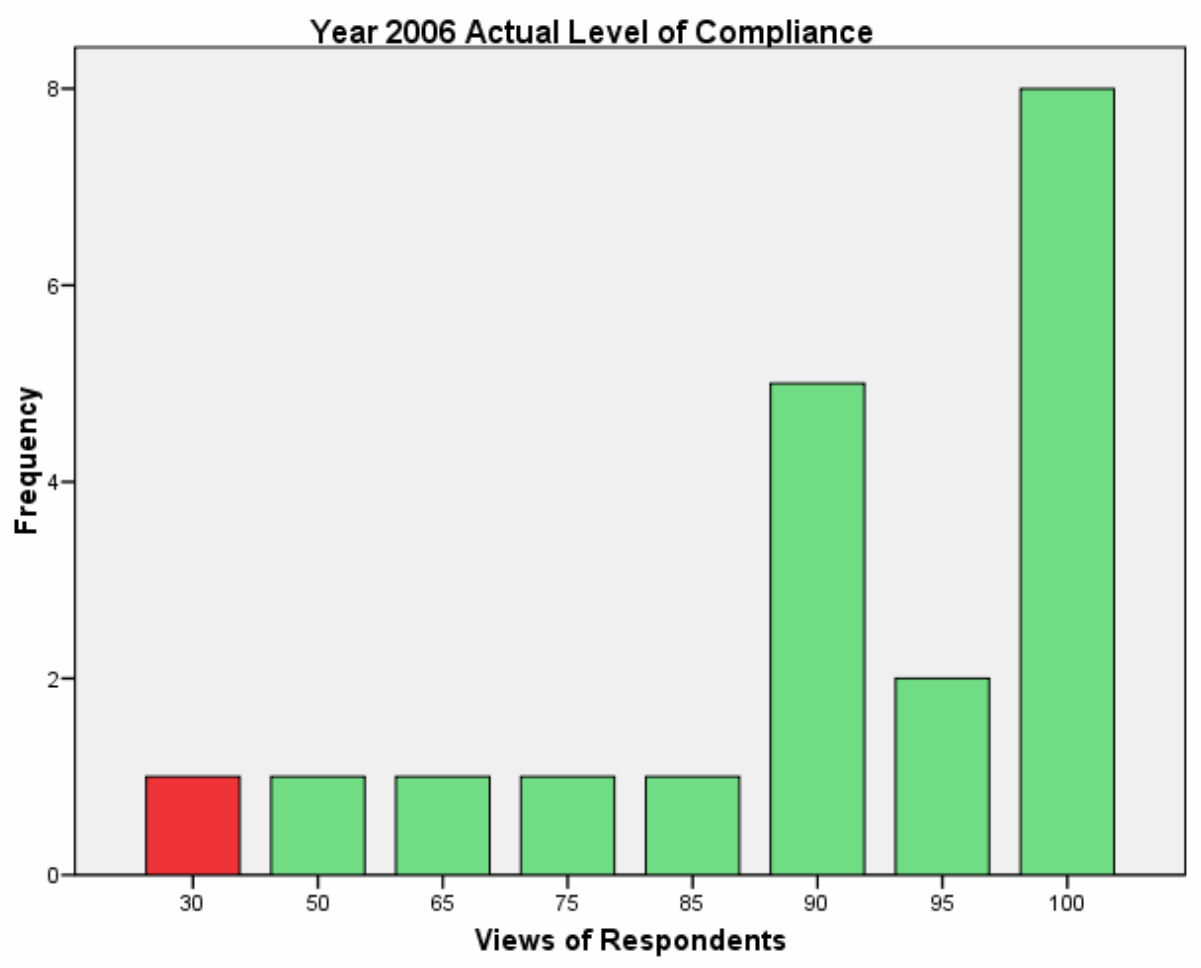


These graphs demonstrate a number of points, first the respondents' low levels of compliance self-estimation in $2000 .^{52}$ They also show considerably higher levels of selfestimated compliance in the most recent year 2006, and over the intervening years there is a slow but noticeable shift to the right-hand side of the graph. This is perhaps due to greater awareness of the significant fines imposed under UK competition law in recent years but probably mainly reflects the fact that there has been an infringement decision against the organisation at some stage during this period, following which it would be anticipated, in accordance with the Australian compliance study, that greater steps would be taken to ensure compliance. Nonetheless, self-estimated levels of compliance should be treated with caution, and, as demonstrated below, it is clearly not reflected in the extent to which organizations have actually implemented key elements of a compliance programme.

(d) Knowledge of Act

Table 4

\begin{tabular}{|l|l|l|l|l|l|l|}
\hline Views on: & $\begin{array}{l}\text { Strongly } \\
\text { disagree }\end{array}$ & Disagree & Neither & Agree & $\begin{array}{l}\text { Strongly } \\
\text { agree }\end{array}$ & $\begin{array}{l}\text { Scale } \\
(\mathbf{1 - 5})\end{array}$ \\
\hline $\begin{array}{l}\text { Believe organisation } \\
\text { and employees well- } \\
\text { informed re Act }\end{array}$ & 5 & 15 & 15 & 40 & 25 & $\mathbf{3 . 6 5}$ \\
\hline
\end{tabular}

Table 5

\begin{tabular}{|l|l|l|l|l|l|l|}
\hline Views on: & $\begin{array}{l}\text { Very } \\
\text { badly }\end{array}$ & badly & Neither & Well & $\begin{array}{l}\text { Very } \\
\text { well }\end{array}$ & $\begin{array}{l}\text { Scale } \\
(1-5)\end{array}$ \\
\hline Believe organisation & 10 & 15 & 45 & 25 & 5 & 3 \\
\hline
\end{tabular}

${ }^{52}$ Cf Rodger supra $\mathrm{n}$ 9, where $77.3 \%$ responded that they had a specific competition compliance programme or as part of $\mathrm{w}$ wider regulatory compliance programme. $59.6 \%$ responded that they had changed or planned to change their compliance programme to take account of the 1998 Act. 


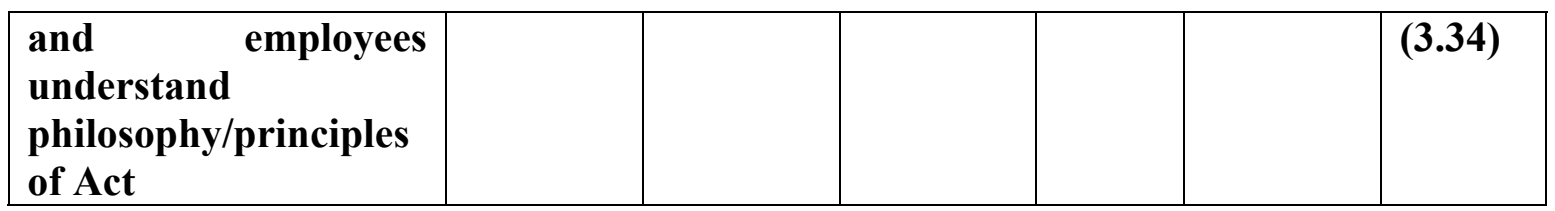

Tables 4 and 5 detail the respondents' answers to two key questions regarding their knowledge and understanding of the Competition Act 1998. Impressively, 65\% agreed, or agreed strongly, with the belief that their organisation and employees were well-informed about the Act. The mean of 3.65 is accordingly very high and one of the few instances throughout the research where the figure for compliance or awareness is higher than under the Australian compliance study (3.42), despite the expectation derived from the latter that compliance commitment would be anticipated to be greater generally postinfringement or "brush with the authorities". ${ }^{53}$ Nonetheless, unfortunately this response is not reflected in respect of the range of more specific and detailed questions regarding compliance programmes and practice, considered further infra.

\section{(e) Impact of Act on Your Organisation}

The following sections consider various aspects of the ways in which businesses may seek to ensure compliance with competition law, and form the key aspect of the research process. In the first section we will assess the extent to which a compliance management system has been put in place in practice by asking statements about things that organizations do to ensure compliance with competition law, and assessing whether respondents agreed with the various statements, as set out in Table 5 and Graph 5. Thereafter we will consider the extent to which various key elements of a compliance

\footnotetext{
${ }^{53}$ See Nielsen and Parker, 2005 Report, supra n 20 supra, 69. In Rodger, supra n 9, 56\% claimed to be fully aware of the 1998 Act, the figure for partially and fully aware combined was $82.3 \%$, and this figure increased to $93.6 \%$ including those simply aware of the Act.
} 
programme form part of that organisation's internal management systems. ${ }^{54}$ These more specific questions, as set out in Tables 6-9, help us to understand the extent to which compliance has been embedded in the company's management systems. ${ }^{55}$ Table 10 provides a comparison with the results from the Australian compliance study in relation to the key elements of a compliance programme. To test the extent to which the impact of the Competition Act 1998 and the compliance message had been integrated within the organization we asked whether internal or external lawyers or other professionals were contacted for advice in the context of a range of potentially anti-competitive situations, and the responses are detailed in Table 11.

Table 5

\begin{tabular}{|l|l|l|l|l|l|l|}
\hline Views On: & $\begin{array}{l}\text { Strongly } \\
\text { Disagree }\end{array}$ & Disagree & Neither & Agree & $\begin{array}{l}\text { Strongly } \\
\text { Agree }\end{array}$ & $\begin{array}{l}\text { Scale } \\
(1-5)\end{array}$ \\
\hline $\begin{array}{l}\text { Invest a Lot of Time and } \\
\text { Money in Compliance } \\
\text { Training }\end{array}$ & $\mathbf{1 5}$ & $\mathbf{4 0}$ & $\mathbf{4 0}$ & $\mathbf{5}$ & $\mathbf{0}$ & $\begin{array}{l}\mathbf{2 . 4} \\
(2.94)\end{array}$ \\
\hline $\begin{array}{l}\text { Compliance requirements } \\
\text { integrated into daily } \\
\text { operating procedures }\end{array}$ & $\mathbf{1 0}$ & 40 & 5 & 40 & 5 & $\begin{array}{l}2.9 \\
(3.69)\end{array}$ \\
\hline $\begin{array}{l}\text { Managers aware of } \\
\text { compliance responsibilities }\end{array}$ & 5 & 20 & 10 & 65 & 0 & $\begin{array}{l}3.35 \\
(3.61)\end{array}$ \\
\hline $\begin{array}{l}\text { Compliance staff easy } \\
\text { access to top management }\end{array}$ & 5 & 10 & 10 & 50 & 25 & $\begin{array}{l}3.8 \\
(4.1)\end{array}$ \\
\hline $\begin{array}{l}\text { Compliance problems } \\
\text { quickly communicated }\end{array}$ & 5 & 5 & 20 & 60 & 10 & $\begin{array}{l}3.65 \\
(3.99)\end{array}$ \\
\hline Compliance programme & 5 & 35 & 50 & 10 & 0 & 2.65 \\
\hline
\end{tabular}

54 See for example, O’Meara, “Corporate Antitrust Compliance Programmes” [1988] European Competition Law Review 59; Marks "Setting up an Anti-Trust Compliance Programme" [1988] European Competition Law Review 59; C Parker, "Evaluating Regulatory Compliance: Standards and Best Practice" (1999) 7 The Trade Practices Journal 62; B Rodger, “Competition Law Compliance Programmes: A study of Motivations and Practice" (2005) World Competition 349, 361-371.

${ }^{55}$ See Rodger, ibid, 371-374. 


\begin{tabular}{|l|l|l|l|l|l|l|}
\hline reviewed regularly & & & & & & $(3.39)$ \\
\hline $\begin{array}{l}\text { Adequate resources to } \\
\text { implement compliance } \\
\text { policy }\end{array}$ & 0 & 30 & 50 & 10 & 10 & 3.5 \\
\hline $\begin{array}{l}\text { Systematic non-compliance } \\
\text { always reported to } \\
\text { authority figures }\end{array}$ & 0 & 5 & 45 & 45 & 5 & 3.5 \\
\hline
\end{tabular}

In every category in Table 5 the mean figure is lower than under the Australian compliance study, ${ }^{56}$ surprising given the anticipation of greater compliance commitment following investigation/sanction by the relevant competition authorities. At least on a comparative basis, the respondents neither invest a lot of time and money in compliance training (55 disagreed/ disagreed strongly) nor consider that adequate resources were available to implement the compliance policy (only $20 \%$ agreed/agreed strongly). There is a link to the perceived costs and gains of compliance/non-compliance which will be considered further infra. A key aspect of compliance management is evaluation/review/auditing ${ }^{57}$ and the respondents appear to be weak here with only $10 \%$ agreeing that their compliance programme was reviewed regularly. ${ }^{58}$

\section{Graph 5}

\footnotetext{
${ }^{56}$ C Parker, and V L Nielsen, "Corporate Compliance Systems: Could they make any difference?" forthcoming at p42.

${ }^{57}$ See for instance C Parker, "Evaluating Regulatory Compliance: Standards and Best Practice" (1999) 7 The Trade Practices Journal 62.

${ }^{58}$ See Rodger, supra $\mathrm{n} 9$, which noted at that stage that only $41.1 \%$ of respondents undertook evaluation as part of their compliance programme.
} 


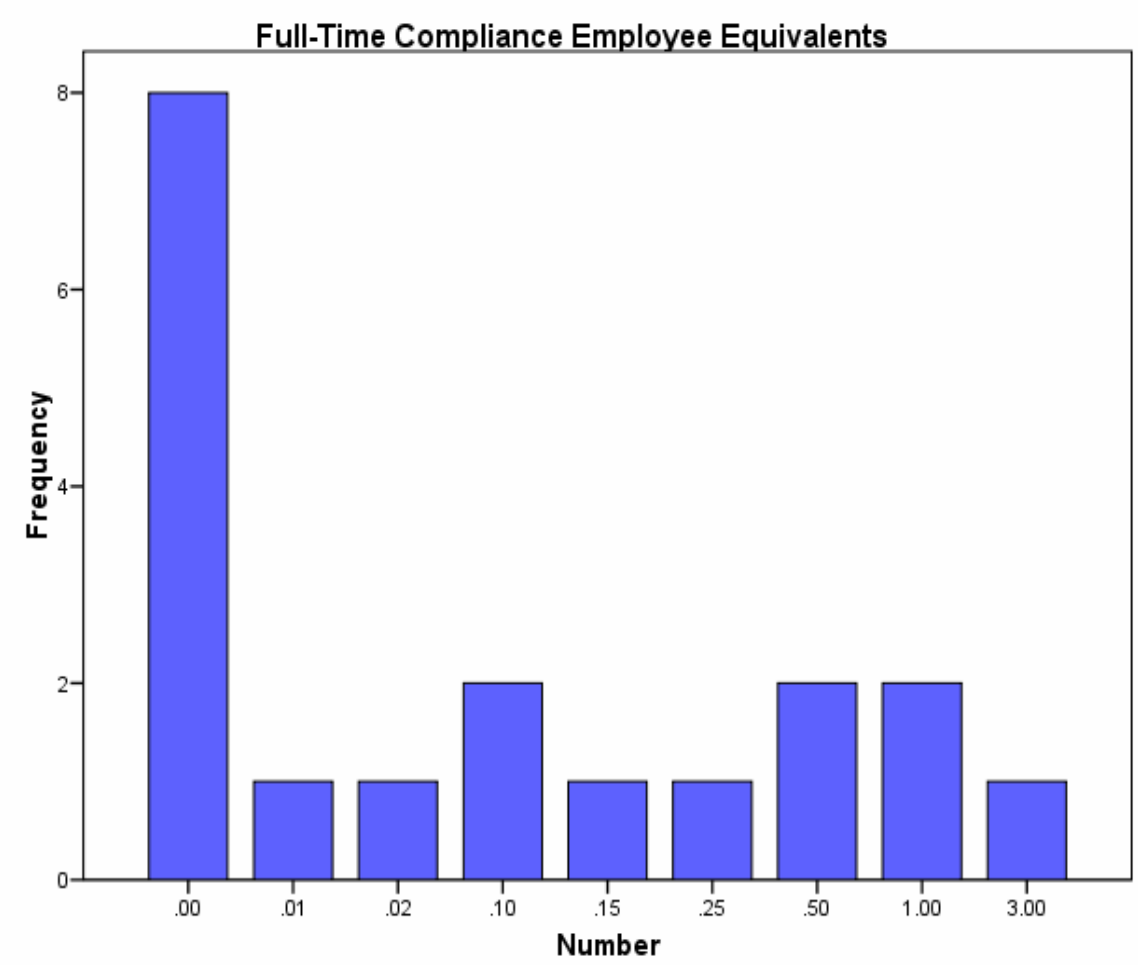

It is notable from Graph 5 that only three respondents had one or more full-time compliance employee equivalents and $73.7 \%$ of respondents had less than a half full-time employee equivalent, whereas under the Australian study, $41 \%$ had at least one full-time dedicated compliance employee. Nonetheless, the number of compliance-related staff alone is a necessary but insufficient test for adequate compliance, and it is informative to assess the extent to which the main elements of an ideal compliance programme have been adopted.

\section{(f) Key elements of Compliance}

The key elements of compliance have been broken down into four key groups, within which each of the specific issues is related: complaints handling, communication and training; Management Accountability and Whistle-blowing; and Compliance Performance Measurement/Discipline as set out in Tables 6-9. 
Kev Elements of Compliance 1-Complaints Handling

Table 6

\begin{tabular}{|l|l|l|}
\hline Complaints Handling & Yes & No \\
\hline Record of Complaints Kept & 60 & 40 \\
\hline Clear system for handling compliance failures & 35 & 65 \\
\hline
\end{tabular}

Key elements of Compliance 2- Communication and Training

Table 7

\begin{tabular}{|l|l|l|}
\hline Communication and Training & Yes & No \\
\hline Organisation has a dedicated compliance unit & $\mathbf{O}$ & $\mathbf{1 0 0}$ \\
\hline New employees given competition compliance training & 15 & 85 \\
\hline Compliance manual used in compliance training & 0 & 100 \\
\hline $\begin{array}{l}\text { At least half of employees attended Act Seminar in last 5 } \\
\text { yrs }\end{array}$ & $\mathbf{5}$ & $\mathbf{9 5}$ \\
\hline Organisation has written compliance policy & 20 & $\mathbf{8 0}$ \\
\hline Occasional refresher course on compliance & $\mathbf{0}$ & $\mathbf{1 0 0}$ \\
\hline OFT staff invited for talk/seminar in last 5 years & 5 & 95 \\
\hline Training session as part of compliance training & 0 & 95 \\
\hline Computer based training programme used & 0 & 95 \\
\hline
\end{tabular}

Kev elements of Compliance 3-Management Accountability and Whistle-blowing

Table 8

\begin{tabular}{|l|l|l|}
\hline Management Accountability and Whistle-Blowing & Yes & No \\
\hline $\begin{array}{l}\text { Written policies to encourage and protect whistle- } \\
\text { blowers }\end{array}$ & 15 & 85 \\
\hline Managers report regularly on compliance & 15 & 85 \\
\hline $\begin{array}{l}\text { Systematic audits by externals for competition law } \\
\text { breaches }\end{array}$ & 5 & 95 \\
\hline External consultant reviewed programme in last 5 years & 25 & 75 \\
\hline
\end{tabular}

$\underline{\text { Key elements of Compliance 4-Compliance Performance Measurement/Discipline }}$

Table 9

\begin{tabular}{|l|l|l|}
\hline Compliance performance measurement & Yes & No \\
\hline $\begin{array}{l}\text { Employees disciplined for breaching compliance } \\
\text { programme in last 5 years }\end{array}$ & 10 & 90 \\
\hline
\end{tabular}


Table 10 collates the information by providing the banded mean figure for each category, based on yes $=1$ and no $=0$, and compares this with the similar result from the Australian study.

Table 10

\begin{tabular}{|l|l|l|}
\hline Compliance Element & Current Research & Australian Study \\
\hline Complaints Handling & $\mathbf{0 . 4 8}$ & $\mathbf{0 . 5 7}$ \\
\hline $\begin{array}{l}\text { Communication and } \\
\text { Training }\end{array}$ & $\mathbf{0 . 0 5}$ & $\mathbf{0 . 3 1}$ \\
\hline $\begin{array}{l}\text { Management } \\
\text { Accountability and } \\
\text { Whistle-blowing }\end{array}$ & $\mathbf{0 . 1 5}$ & $\mathbf{0 . 3 0}$ \\
\hline $\begin{array}{l}\text { Compliance Performance } \\
\text { Measurement/Discipline }\end{array}$ & $\mathbf{0 . 1 0}$ & $\mathbf{0 . 1 3}$ \\
\hline
\end{tabular}

It should be emphasized that although the questions within the Communication and Training and Management Accountability and Whistle-blowing groups were virtually identical, the Australian compliance study contained more consumer-oriented questions in the Complaints Handling group and also additional questions in the final Compliance Performance Measurement/Discipline set which were not considered as important or relevant in this context. The outcomes in the two studies are notably differentiated in relation to management accountability and whistle-blowing and even more dramatic for the communication and training group. The results of the current study for these elements are disappointing, noting in particular that none of the respondents have a dedicated compliance unit, and that $85 \%$ responded No to whether new employees were given compliance training. ${ }^{59}$ Moreover, given the importance of communication from top-down

\footnotetext{
${ }^{59}$ cf Rodger, supra $\mathrm{n} 9$, where $51.8 \%$ responded that all relevant staff received training on competition issues. This is particularly notable given the greater likelihood of implementation of the various elements after a firm had experienced an ACCC breach investigation, which suggested, according to Parker and
} 
about a corporate culture of compliance and for employees to understand and engage with the compliance policy, it renders the responses regarding self-estimated levels of compliance in recent years, as discussed below, surprisingly optimistic. Even in the Australian compliance study, it was concluded that implementation of compliance systems by Australian businesses was partial, ${ }^{60}$ and it has been argued that attempts at compliance may in any event be simply symbolic. ${ }^{61}$ Nonetheless, Parker and Nielsen identified a clear correlation between implementation of compliance elements and enhanced compliance management in practice, and accordingly, implementation of key elements of a compliance programme may be a proxy for effective compliance. ${ }^{62}$ Accordingly there is an important role for regulators, such as the OFT, to educate, promote and encourage the adoption and implementation of a range of key elements of standard compliance programmes, noting in particular the very weak performance of the respondents in this study in relation to aspects of communication and training.

\section{(g)Compliance in Practice}

\section{Table 11}

\footnotetext{
Nielsen, supra $\mathrm{n} 16,476$, that enforcement activity "is very important for pushing firms beyond the most commonly implemented compliance system elements - ...towards deeper implementation.”

${ }^{60}$ Parker and Nielsen, supra n 16, 444.

${ }^{61}$ D C Langevoort, "Monitoring: The Behavioural Economics of Corporate Compliance with Law" (2002)

71 Columbia Business Law Review 114.

${ }^{62}$ Parker and Nielsen, supra n 16,478-479. See also C Parker, and V L Nielsen, "Do Corporate Compliance Programs Influence Compliance? (September 2006) Social Science Research Network http://ssrn.com/abstract=930238 accessed on 5 April 2008.
} 


\begin{tabular}{|l|l|l|l|l|l|}
\hline Scenarios: & Never & Sometimes & Mostly & Always & $\begin{array}{l}\text { Have never had } \\
\text { any such activity }\end{array}$ \\
\hline $\begin{array}{l}\text { Competitor contacts to } \\
\text { discuss aspects of the market }\end{array}$ & 35 & 25 & 5 & 5 & 20 \\
\hline $\begin{array}{l}\text { Sharing information with } \\
\text { your industry association }\end{array}$ & 45 & 30 & 0 & 0 & 25 \\
\hline $\begin{array}{l}\text { Sharing info with other } \\
\text { organizations/competitors }\end{array}$ & 40 & 25 & 0 & 0 & 35 \\
\hline $\begin{array}{l}\text { Attending industry } \\
\text { association meetings }\end{array}$ & 45 & 30 & 0 & 0 & 25 \\
\hline
\end{tabular}

Table 11 details the respondents' answers relating to the frequency with which they would ask for advice about the Competition Act from internal/external lawyers or other professionals in connection with those activities. Perhaps the most worrying aspect is that $30 \%$ would never or only sometimes seek advice where a competitor contacted to discuss aspects of the market, a situation which should immediately raise concerns about prohibited collusive behaviour between competitors.

(h) Costs and Benefits of Complying with the Act

Table 12

\begin{tabular}{|l|l|l|l|l|l|l|}
\hline Compliance Costs & $\begin{array}{l}\text { Very } \\
\text { small }\end{array}$ & Small & Neither & Large & $\begin{array}{l}\text { Very } \\
\text { large }\end{array}$ & $\begin{array}{l}\text { Scale } \\
(1-5)\end{array}$ \\
\hline Administrative costs & 40 & 50 & 10 & 0 & 0 & $\begin{array}{l}1.7 \\
(2.17)\end{array}$ \\
\hline $\begin{array}{l}\text { Expenses on } \\
\text { lawyers/compliance } \\
\text { professionals }\end{array}$ & 45 & 25 & 20 & 5 & 5 & $\begin{array}{l}2 \\
(2.53)\end{array}$ \\
\hline $\begin{array}{l}\text { Costs of compliance systems } \\
\text { and training }\end{array}$ & 45 & 25 & 20 & 0 & 5 & $\begin{array}{l}1.9 \\
(2.26)\end{array}$ \\
\hline
\end{tabular}

Table 12 details the respondents' answers to three questions concerning their beliefs about the costs of compliance with the Competition Act. The mean answer to the responses is noted on the basis of the scale $1-5$, from very small (1) to very large (5). The responses indicate the very low costs incurred by the respondent organisations in relation 
to compliance. On the one hand, it is surprising that in each category the perceived costs are lower than in the Australian compliance study, ${ }^{63}$ given that all respondents have been involved in infringement proceedings, but the results are consistent with the weak performance of the respondents in relation to the communication and training aspects of compliance, though potentially inconsistent with the self-estimated compliance levels.

Table 13

\begin{tabular}{|l|l|l|l|l|l|l|l|}
\hline Compliance Gains & $\begin{array}{l}\text { No } \\
\text { gain }\end{array}$ & $\begin{array}{l}\text { Very } \\
\text { small }\end{array}$ & Small & Neither & Large & $\begin{array}{l}\text { Very } \\
\text { Large }\end{array}$ & $\begin{array}{l}\text { Scale } \\
(1-6)\end{array}$ \\
\hline Better monitoring tools & $\mathbf{3 0}$ & $\mathbf{2 0}$ & $\mathbf{5}$ & $\mathbf{3 5}$ & $\mathbf{1 0}$ & $\mathbf{0}$ & $\begin{array}{l}\mathbf{2 . 7 5} \\
(3.22)\end{array}$ \\
\hline $\begin{array}{l}\text { Better knowledge of our } \\
\text { organisation }\end{array}$ & $\mathbf{3 5}$ & $\mathbf{2 0}$ & $\mathbf{0}$ & $\mathbf{4 0}$ & $\mathbf{5}$ & $\mathbf{0}$ & $\begin{array}{l}\mathbf{3 . 4 5} \\
(3.94)\end{array}$ \\
\hline Better Image & $\mathbf{2 5}$ & $\mathbf{0}$ & $\mathbf{1 0}$ & $\mathbf{3 5}$ & $\mathbf{3 0}$ & $\mathbf{0}$ & $\begin{array}{l}\mathbf{3 . 4 5} \\
(3.94)\end{array}$ \\
\hline Absence of OFT Problems & $\mathbf{1 0}$ & $\mathbf{5}$ & $\mathbf{1 0}$ & $\mathbf{2 5}$ & $\mathbf{2 0}$ & $\mathbf{3 0}$ & $\begin{array}{l}\mathbf{4 . 3} \\
(4.06)\end{array}$ \\
\hline
\end{tabular}

Table 13 details the respondents' answers to four questions concerning their beliefs about the potential business gains of compliance with the Competition Act. The mean answer to the responses is noted on the basis of the scale $1-6$, from no gain (1) to very large (6). The responses indicate a generally low recognition of the potential gains of compliance, with the exception of the absence of OFT problems where $50 \%$ considered this to be a large/very large gain associated with compliance and the mean was higher than under the Australian compliance study, ${ }^{64}$ as could be anticipated in research focused on postinfringement respondents. Apart from this result, in both studies respondents generally perceived the costs and gains of compliance as fairly low, although clearly there is scope

\footnotetext{
${ }^{63}$ See Parker and Nielsen, supra n 26, 41.

${ }^{64}$ Ibid.
} 
for further work in understanding how firms perceive costs and gains and translate these into decisions on compliance management.

(i) Compliance and Enforcement problem Scenarios

Table 14

\begin{tabular}{|l|l|l|l|l|l|l|}
\hline Problem: & $\begin{array}{l}\text { Very } \\
\text { Small }\end{array}$ & Small & Neither & Large & $\begin{array}{l}\text { Very } \\
\text { large }\end{array}$ & $\begin{array}{l}\text { Scale } \\
(1-5)\end{array}$ \\
\hline $\begin{array}{l}\text { OFT Chair announces } \\
\text { investigation at press } \\
\text { conference }\end{array}$ & 10 & 5 & 0 & 25 & 60 & $\begin{array}{l}4.20 \\
(4.51)\end{array}$ \\
\hline OFT Fine £100k & 5 & 0 & 0 & 25 & 50 & $\begin{array}{l}4.55 \\
(4.48)\end{array}$ \\
\hline OFT Fine £1m & 0 & 5 & 5 & 0 & 90 & $\begin{array}{l}4.79 \\
(4.84)\end{array}$ \\
\hline $\begin{array}{l}\text { OFT Fine 10\% Turnover } \\
\text { Improved Compliance and } \\
\text { Consumer Compensation } \\
\text { £100k }\end{array}$ & 0 & 0 & 0 & 5 & 95 & $\begin{array}{l}4.95 \\
(4.92)\end{array}$ \\
\hline $\begin{array}{l}\text { Improved Compliance and } \\
\text { Consumer compensation £1m }\end{array}$ & 0 & 0 & 15 & 0 & 85 & $\begin{array}{l}4.7 \\
(4.82)\end{array}$ \\
\hline $\begin{array}{l}\text { Loss of morale in organisation } \\
\text { Criminal conviction and }\end{array}$ & 0 & 0 & 25 & 30 & 45 & $\begin{array}{l}4.2 \\
(4.02)\end{array}$ \\
prison & 0 & 0 & 0 & 5 & 95 & $\begin{array}{l}4.95 \\
(4.85)\end{array}$ \\
\hline \begin{tabular}{l} 
Private law suit \\
\hline
\end{tabular} & 0 & 0 & 10 & 5 & 85 & $\begin{array}{l}4.75 \\
(4.69)\end{array}$ \\
\hline
\end{tabular}

Table 14 details the respondents' answers to a range of questions concerning their beliefs about the costs of non-compliance with the Competition Act, by asking how much of a problem senior management would find those costs if they were ever caught by the OFT breaching the Act. The mean answer to the responses is noted on the basis of the scale 15, from very small (1) to very large (5). The responses indicate a remarkably similar outcome as in relation to the series of virtually identical questions under the Australian 
compliance study, ${ }^{65}$ in which the responses indicate a very high concern with the various potential costs of non-compliance. Mirroring that study, there is some variation with certain costs inevitably perceived as greater than others, ${ }^{66}$ and the most serious clearly perceived as being a fine of $10 \%$ turnover and a criminal conviction and prison sentence for an individual. Heavier sanctions clearly focus management on compliance although it has been argued that punitive sanctions can be counter-productive. ${ }^{67}$

\section{(j) Third party influence- Economic Losses and Loss of Third Party Respect/esteem}

As discussed above, third parties, notably social and economic stakeholders, may play an important role in promoting compliance commitment, and the extent to which businesses take third parties into account is examined in the data set out on Tables 15 and 16.

Table 15

\begin{tabular}{|l|l|l|l|l|l|l|}
\hline Economic Losses & $\begin{array}{l}\text { Worry } \\
\text { very } \\
\text { little }\end{array}$ & $\begin{array}{l}\text { Worry } \\
\text { a little }\end{array}$ & Neither & $\begin{array}{l}\text { Worry } \\
\text { a lot }\end{array}$ & $\begin{array}{l}\text { Worry } \\
\text { very } \\
\text { much }\end{array}$ & $\begin{array}{l}\text { Scale } \\
(1-5)\end{array}$ \\
\hline Your suppliers & $\mathbf{3 5}$ & $\mathbf{3 0}$ & $\mathbf{5}$ & $\mathbf{1 0}$ & $\mathbf{2 0}$ & $\mathbf{2 . 5}$ \\
\hline
\end{tabular}

\footnotetext{
${ }^{65}$ See Parker and Nielsen, supra n 26, 24. It should be noted that the Australian compliance study referred to fines in Aus $\$$ and the current study refers to GB pound sterling (£).

${ }^{66}$ Note that in relation to the question regarding an OFT Fine of £1mill, one respondent noted N/A. Although this was placed in the neither category in the Table, the mean was calculated on the basis of the other 19 responses.

${ }^{67}$ See for instance Parker and Nielsen, supra n 26, 26, noting that their responses tallied "with the observation in other empirical research on deterrence that there is no linear relationship between the severity of penalties available and the fear or perceived costs of those penalties among those at whom regulation is targeted- greater penalties do not automatically mean greater deterrence in equal measure." It has been argued accordingly that heavy-handed punishment may act as a disincentive or cause resistance to enhanced compliance efforts.
} 


\begin{tabular}{|l|l|l|l|l|l|l|}
\hline & & & & & & $(\mathbf{2 . 8 2})$ \\
\hline Your industry association & 20 & 20 & 30 & 10 & 20 & $\begin{array}{l}2.9 \\
(2.73)\end{array}$ \\
\hline Consumer Groups/NGOs & 10 & 15 & 35 & 20 & 20 & $\begin{array}{l}3.25 \\
(3.13)\end{array}$ \\
\hline Your Business partners & 0 & 20 & 20 & 20 & 40 & $\begin{array}{l}3.4 \\
(3.5)\end{array}$ \\
\hline Your shareholders & 0 & 0 & 30 & 20 & 45 & $\begin{array}{l}4.16 \\
(4.08)\end{array}$ \\
\hline Your customers & 10 & 5 & 10 & 30 & 45 & $\begin{array}{l}3.95 \\
(4.18)\end{array}$ \\
\hline Your employees & 5 & 10 & 15 & 30 & 40 & $\begin{array}{l}3.9 \\
(3.87)\end{array}$ \\
\hline Informal business networks & 10 & 20 & 35 & 15 & 20 & $\begin{array}{l}3.15 \\
(2.99)\end{array}$ \\
\hline The media & 5 & 15 & 30 & 30 & 20 & $\begin{array}{l}3.45 \\
(3.52)\end{array}$ \\
\hline
\end{tabular}

Table 15 details the respondents' answers to the following question: - If your organization were accused again of breaches of the Competition Act in future, how much would your organization worry about economic losses in relation to the following groups of people? The mean answer to the responses is noted on the basis of the scale 1-5, from worry very little (1) to worry very much (5). Throughout, as denoted by the mean answer, the outcome is very similar in virtually all respects as under the Australian compliance study ${ }^{68}$ although, in respect of economic losses, there is more concern with shareholders than with customers in a UK context.

Table 16

\begin{tabular}{|l|l|l|l|l|l|l|}
\hline Loss of Respect/Esteem & $\begin{array}{l}\text { Worry } \\
\text { very } \\
\text { little }\end{array}$ & $\begin{array}{l}\text { Worry } \\
\text { a little }\end{array}$ & Neither & $\begin{array}{l}\text { Worry } \\
\text { a lot }\end{array}$ & $\begin{array}{l}\text { Worry } \\
\text { very } \\
\text { much }\end{array}$ & $\begin{array}{l}\text { Scale } \\
(\mathbf{1 - 5})\end{array}$ \\
\hline Your suppliers & 25 & 15 & 15 & 20 & 25 & $\begin{array}{l}\mathbf{3 . 0 5} \\
(3.26)\end{array}$ \\
\hline Your industry association & 15 & 15 & 25 & 20 & 25 & 3.25 \\
\hline
\end{tabular}

${ }^{68}$ C Parker and V L Nielsen "To What Extent do Third Parties Influence Business Compliance" forthcoming at 10 . 


\begin{tabular}{|l|l|l|l|l|l|l|}
\hline Consumer Groups/NGOs & 10 & 25 & 20 & 25 & 20 & $\begin{array}{l}(3.27) \\
(3.51)\end{array}$ \\
\hline Your business partners & 5 & 15 & 25 & 30 & 25 & $\begin{array}{l}3.55 \\
(3.83)\end{array}$ \\
\hline Your shareholders & 10 & 5 & 30 & 5 & 45 & $\begin{array}{l}3.55 \\
(4.22)\end{array}$ \\
\hline Your customers & 10 & 0 & 10 & 30 & 50 & $\begin{array}{l}4 \\
(4.41)\end{array}$ \\
\hline Your employees & 10 & 20 & 20 & 25 & 25 & $\begin{array}{l}3.35 \\
(4.13)\end{array}$ \\
\hline Informal business networks & 20 & 5 & 40 & 15 & 20 & $\begin{array}{l}3.1 \\
(3.21)\end{array}$ \\
\hline The media & 10 & 5 & 25 & 40 & 20 & $\begin{array}{l}3.55 \\
(3.66)\end{array}$ \\
\hline $\begin{array}{l}\text { Lawyers/Compliance } \\
\text { professionals }\end{array}$ & 30 & 30 & 10 & 15 & 15 & $\begin{array}{l}2.55 \\
(3.14)\end{array}$ \\
\hline Relatives & 35 & 15 & 20 & 5 & 25 & $\begin{array}{l}2.7 \\
(3.03)\end{array}$ \\
\hline Politicians & 40 & 25 & 20 & 5 & 10 & $\begin{array}{l}2.2 \\
(3.13)\end{array}$ \\
\hline
\end{tabular}

Table 16 details the respondents' answers to the following question: - If your organization were accused again of breaches of the Competition Act in future, how much would your organization worry about losing the respect and esteem of the following groups of people? The mean answer to the responses is noted on the basis of the scale 15 , from worry very little (1) to worry very much (5). A considerably lower proportion of respondents were concerned about loss of respect/esteem than economic losses in relation to shareholders. Generally, there is a discernibly lower concern for loss of respect/esteem across the categories of third parties in comparison with the Australian compliance study where social losses in relation to third parties were viewed as being equally severe as their economic losses, ${ }^{69}$ with the results for shareholders, customers, employees and

${ }^{69}$ Ibid, 10-11. 
politicians in the current study notably lower, suggesting a lower social and/or political motivation to comply with the law. This is particularly surprising given that slightly more of those who interacted with ACCC perceived the social costs of non-compliance as higher than the economic costs..$^{70}$ Nielsen and Parker, despite skepticism regarding the direct role of third parties currently in driving compliance commitment, ${ }^{71}$ have emphasized the capacity and potential role for customers and shareholders in particular to 'activate most businesses' economic and social motivations to support... compliance. ${ }^{, 72}$ Furthermore, although recognizing that third parties lack a more focused interest in compliance in competition and consumer law and policy than in other areas such as environmental regulation, they advocate action by the enforcement agency, such as the ACCC, or the OFT, to encourage and enhance the role of such third parties in promoting better compliance by those businesses in which they are stakeholders. ${ }^{73}$

\section{(j) Economic Gains of Breach}

Table 17

\begin{tabular}{|l|l|l|l|l|l|l|l|}
\hline Economic Gains & $\begin{array}{l}\text { Not } \\
\text { Relevant }\end{array}$ & $\begin{array}{l}\text { Very } \\
\text { Small }\end{array}$ & Small & Neither & Large & $\begin{array}{l}\text { Very } \\
\text { large }\end{array}$ & $\begin{array}{l}\text { Scale } \\
(1-6)\end{array}$ \\
\hline $\begin{array}{l}\text { Saved production } \\
\text { costs }\end{array}$ & $\mathbf{4 0}$ & $\mathbf{2 5}$ & $\mathbf{0}$ & $\mathbf{3 0}$ & $\mathbf{0}$ & $\mathbf{5}$ & $\mathbf{2 . 4}$ \\
\hline Gain of market share & $\mathbf{2 0}$ & $\mathbf{3 5}$ & $\mathbf{5}$ & $\mathbf{1 0}$ & $\mathbf{1 5}$ & $\mathbf{1 0}$ & $\mathbf{3 . 0 5}$ \\
\hline $\begin{array}{l}\text { Saved competition } \\
\text { costs }\end{array}$ & $\mathbf{2 0}$ & $\mathbf{2 5}$ & $\mathbf{1 5}$ & $\mathbf{3 0}$ & $\mathbf{5}$ & $\mathbf{5}$ & $\mathbf{2 . 9}$ \\
\hline
\end{tabular}

\footnotetext{
${ }^{70} \mathrm{Ibid}$.

${ }^{71} \mathrm{Ibid}, 28$ :- "There is little evidence in our study that the mere existence of stakeholder relationships is sufficient to 'drive' differences in business compliance management behaviour."

${ }^{72}$ Ibid, 11. See also J Black, "Enrolling Actors in Regulatory Processes: Examples from UK Financial services Regulation” (2003) Public Law 62.

${ }^{73}$ Parker and Nielsen, supra n 68, 30.
} 


\begin{tabular}{|l|l|l|l|l|l|l|l|}
\hline $\begin{array}{l}\text { Saved paperwork } \\
\text { time and money }\end{array}$ & 20 & 25 & 15 & 30 & 5 & 5 & 2.95 \\
\hline $\begin{array}{l}\text { Instant one shot } \\
\text { economic gain }\end{array}$ & 20 & 30 & 10 & 25 & 10 & 0 & 2.74 \\
\hline $\begin{array}{l}\text { Saved costs on } \\
\text { lawyers/compliance } \\
\text { professionals }\end{array}$ & 15 & 30 & 10 & 20 & 0 & 25 & 3.35 \\
\hline
\end{tabular}

Table 17 details the respondents' answers to the following question: - How large were the economic gains from breaching the Act? The mean answer to the responses is noted on the basis of the scale $1-6$, from not relevant (1) to very large (6). ${ }^{74}$ In the Australian compliance study, the highest gains were considered to be in respect of market share, whereas a much lower figure was obtained for the gains in respect of saved costs on lawyers/compliance professional fees, ${ }^{75}$ which were considered to be the greatest gains from non-compliance in the present study. This reflects to an extent the lack of concern about the loss of respect/esteem by those professionals as detailed in Table 16, and is also clearly consistent with responses as set out in Tables 5, 7, 11 and 12, confirming the low levels of investment in compliance, the poor performance in terms of ongoing communication and training, the disappointing infrequency with which lawyers are contacted regarding competitor contacts, and the low costs associated with compliance with the Act. In fact the respondents appear to be saying that we spend little in complying, and indeed those cost savings are the greatest gains associated with breach!!

Table 18

\begin{tabular}{|l|l|l|l|l|l|l|}
\hline Economic Gains of & None & Very & Tiny & Substantial & Very & Scale \\
\hline
\end{tabular}

${ }^{74}$ It should be noted that there is no Australian comparative here because the Australian study calculated the mean figures on a scale of 1-5. The 'not relevant' category was included in this study and is deemed to equate to no gain.

${ }^{75}$ Parker and Nielsen supra n 26, 41. 


\begin{tabular}{|l|l|l|l|l|l|l|}
\hline breach: & & Tiny & & & Substantial & $(1-5)$ \\
\hline $\begin{array}{l}\text { Anticipated Income } \\
\text { Improvement in } \\
\text { Last 6 years }\end{array}$ & 5 & 30 & 5 & 5 & 15 & 2.75 \\
\hline
\end{tabular}

Table 18 collates the responses to the question: How large on average would you and your organization estimate to be the expected value of breaches of the Competition Act committed by your organization in the last 6 years? $8,40 \%$, responded 'didn't know', and accordingly the mean of 2.75 was calculated from the remaining 12 responses, and overall the perception from Tables 17 and 18 is that the gains for beach are low, a similar outcome to the Australian compliance study. ${ }^{76}$ In that context, only $6 \%$ considered the gains to be substantial or very substantial, and $55.6 \%$ saw a tiny or very tiny improvement on income, and the results in Table 18 suggest a slightly higher awareness of the potential economic gains from breach of the Competition Act. ${ }^{77}$ Given the generally low levels of perceived gains it is important to consider why organizations do breach the relevant rules.

\section{(k) Why breach Competition Act?}

Table 19

\begin{tabular}{|l|l|l|}
\hline Why Breach? & Yes & No \\
\hline $\begin{array}{l}\text { Did not know we had } \\
\text { breached law }\end{array}$ & 70 & 30 \\
\hline $\begin{array}{l}\text { Thought we would } \\
\text { save/gain a lot of money }\end{array}$ & 15 & $\mathbf{8 5}$ \\
\hline Specific rule breached was & $\mathbf{0}$ & 100 \\
\hline
\end{tabular}

${ }^{76} \mathrm{Ibid}, 38-40$.

${ }^{77}$ This may be partly explained by the focus in the present study on competition issues, as opposed to combined consumer and competition law compliance in the Australian compliance study, and also reflect the fact that all responses were in relation to Chapter I infringements given the potential gains associated with cartel activity. 


\begin{tabular}{|l|l|l|}
\hline $\begin{array}{l}\text { damaging to UK economy } \\
\text { and not to be obeyed }\end{array}$ & & \\
\hline $\begin{array}{l}\text { Relied on incorrect legal } \\
\text { advice }\end{array}$ & $\mathbf{1 0}$ & $\mathbf{9 0}$ \\
\hline $\begin{array}{l}\text { Inadequate management } \\
\text { controls over employees }\end{array}$ & $\mathbf{2 0}$ & $\mathbf{8 0}$ \\
\hline
\end{tabular}

Table 19 provides the responses to the question:-Why did your organization breach the Competition Act? Respondents were allowed to tick more than one of the options, and in addition a small minority, $15 \%$, noted other, unspecified, reason for the breach. The most significant response is clearly the $70 \%$ of respondents who noted that breach was a result of their lack of awareness that they had breached the law, unsurprising given the responses in relation to the perceived costs of compliance and the limited provision of communication and training elements as part of a corporate compliance programme. This also suggests that further educational initiatives by the UK competition authorities may be appropriate.

\section{(l) Crosstabs}

Nielsen and Parker noted that businesses generally rate themselves highly in relation to broad questions about their purported values and estimated levels of compliance, but that the responses are more varied, and generally lower, when asked to respond to more objective or quantifiable specific issues. ${ }^{78}$ This is reflected in the current study and accordingly, we crosstabulated the responses to various questions to ascertain to what extent they were consistent. Table 20 crosstabulates the belief that the organization and employees are well-informed about the Act with the reason for breach being that we did not know they had breached the law. Thirteen organizations agreed or agreed strongly

${ }^{78}$ C Nielsen and V L Parker, Preliminary Report, December 2005, 39. 
with the former proposition, but of those, $9,69.2 \%$, responded that a reason for breach was that they did not know they had breached the law. Nonetheless one must bear in mind the time-lag between breach and the completion of the questionnaire during which knowledge levels among employees may have increased, although this is not evidenced by the responses on communication and training discussed above.

Table 20

\begin{tabular}{|ll|l|l|l|}
\hline \multirow{2}{*}{} & & \multicolumn{2}{|l|}{$\begin{array}{l}\text { Why Breach: Did } \\
\text { Not Know Law }\end{array}$} & \multirow{2}{*}{ Total } \\
\cline { 3 - 4 } & Yes & No & Yes \\
\hline Believe Organisation & Strongly & 1 & 0 & 1 \\
and Employees Well- & disagree & 1 & 0 & \\
Informed about Act & Disagree & 2 & 1 & 3 \\
& Neither & 2 & 1 & 3 \\
& Agree & 6 & 2 & 8 \\
Total & Strongly agree & 3 & 2 & 5 \\
& & 14 & 6 & 20 \\
\hline
\end{tabular}

Similar evidence that the responses to broad subjective questions about beliefs and values generally are not borne out by the evidence from the answers to specific quantifiable questions comes from a crosstabulation of the answers to the question seeking views on the damaging or beneficial nature of agreements to fix prices with the question whether respondents seek advice when sharing information with competitors. As Table 21 demonstrates, despite recognizing the damaging or very damaging nature of price-fixing, respondents fail to see the natural link between this type of activity and a common form of achieving such a price-fixing conspiracy, namely by sharing sensitive information with competitors. Of the 12 respondents who considered price-fixing to be damaging or very damaging, 6 never sought advice and a further 2 only sometimes sought advice when sharing information with a competitor. 
Table 21

\begin{tabular}{|c|c|c|c|c|c|}
\hline \multirow{2}{*}{\multicolumn{2}{|c|}{ Price-fixing agreements }} & \multicolumn{3}{|c|}{$\begin{array}{l}\text { Seek Advice when sharing info } \\
\text { with competitors }\end{array}$} & \multirow[t]{2}{*}{ Total } \\
\hline & & Never & Sometimes & $\begin{array}{l}\text { Have never } \\
\text { had such } \\
\text { an activity }\end{array}$ & \\
\hline $\begin{array}{l}\text { Views of } \\
\text { respondents } \\
\text { Total }\end{array}$ & $\begin{array}{l}\text { Very } \\
\text { damaging } \\
\text { Damaging } \\
\text { Neither } \\
\text { Beneficial }\end{array}$ & $\begin{array}{l}2 \\
3 \\
2 \\
1 \\
8\end{array}$ & $\begin{array}{l}1 \\
\mathbf{1} \\
\mathbf{3} \\
\mathbf{0} \\
\mathbf{5}\end{array}$ & $\begin{array}{l}2 \\
3 \\
2 \\
\mathbf{0} \\
7\end{array}$ & $\begin{array}{l}5 \\
7 \\
7 \\
1 \\
20\end{array}$ \\
\hline
\end{tabular}

We also crosstabulated the respondents' self-estimated culture of compliance in the year 2006 with their responses to the question whether their compliance programme was reviewed regularly. Although review/auditing is generally considered to be a fundamental element of an effective compliance programme, it is notable that of the 7 respondents who self-estimated a $100 \%$ culture of compliance for 2006 , none of those organizations review their compliance programme regularly, further highlighting the limitations of a self-estimation exercise. Nonetheless, despite the numerous apparent contradictions and inconsistencies in the responses across the questionnaire, the information is consistent in some respects, with for instance a correlation between the responses to the measurement of compliance gains in the form of the absence of OFT problems, and respondents' views on whether the OFT had a wide range of sanctions, as of the 10 respondents who considered the gains to be large or very large, 9 agreed or agreed strongly that the OFT had a wide range of effective sanctions.

\section{CONCLUSIONS}

This research was modeled on the Australian compliance study, which had suggested that compliance commitment was likely to increase following competition authority 
infringement action, by being targeted at business which had already been the subject of competition enforcement action in the UK. The response rate was $33 \%$, a satisfactory level albeit with a very small sample which limits any broad conclusions being drawn about compliance attitudes and systems implementation by UK businesses generally. However, although this study itself demonstrated the limitations in self-assessed questionnaire surveys, it provides us with further understanding of the links between regulatory enforcement strategies, industry compliance and other motivating factors generally, while also indicating the disappointing level of compliance system implementation among the respondents. ${ }^{79}$ Although the respondents suggested there were very good levels of awareness of the Competition Act, unfortunately this response was not reflected in respect of the range of more specific and detailed questions. The number of compliance employees in the respondent organisations was low and there is clearly a role for the OFT to educate, promote and encourage the adoption and implementation of a range of key elements of standard compliance programmes, noting the very weak performance of the respondents in this study in relation to aspects of communication and training in particular. ${ }^{80}$ Furthermore, $70 \%$ of respondents noted that breach was a result

\footnotetext{
${ }^{79}$ The responses are not necessarily representative of the full sample, and certainly not of UK industry in general. Indeed, a number of the organisations in the sample were relatively small construction companies and this may at least partly account for the poor performance in terms of compliance system implementation.

${ }^{80}$ For a discussion of the extent to which adoption of compliance management elements actually influences or leads to better actual compliance, see C Parker and V L Nielsen, "Do Corporate Compliance Programs Influence Compliance" and Corporate Compliance Systems: Do they make any Difference?' both forthcoming.
} 
of their lack of awareness that they had breached the law, suggesting that further educational initiatives by the UK competition authorities may be appropriate. The Australian study findings that organisations subjected to enforcement action are more likely to be committed to compliance would present a very worrying picture of compliance practice in the UK generally based on the results, albeit limited, of the present study. In 1999, before the prohibitions came into force the OFT developed a compliance policy, comprising inter alia the publication of guidelines under s52 of the Act, and the OFT sought to increase awareness and compliance by launching an education programme through its Education and Compliance section. At that stage, I suggested that the OFT had adopted a three-pronged strategy or an "enhanced carrot and stick" approach; ${ }^{81}$ incorporating a deterrent strategy; an educative strategy; and a third "legitimising" strategy, involving OFT officials touring the country to explain the nature and rationale of the new legislation. The OFT website currently has a dedicated page on compliance, ${ }^{82}$ and they also have related publications and a CDROM called 'Compliance Matters!' but perhaps this research indicates that the OFT could channel more resources to the educational and informational strategy which was fairly prominent and pro-active at the time the Act was introduced.

Despite the overly subjective nature of a questionnaire involving self-estimated levels of awareness and compliance, business perceptions of the competition authority's role and its impact on compliance strategies, together with a range of other motivating factors,

\footnotetext{
${ }^{81}$ Rodger, supra n 9, 280 -281.

82 http://www.oft.gov.uk/advice_and_resources/resource base/legal/competition-act-1998/compliance accessed on 4 April 2008.
} 
including perceived costs and gains to itself and third parties, help to facilitate a fuller understanding of why businesses may or may not comply with the law. There are, as noted, potentially pluralistic motivations for compliance with legal rules, ${ }^{83}$ and following earlier research, there is some limited support for the three key theoretical frameworks underpinning the promotion of effective compliance- rational-choice based deterrence, moral corporate citizenship based on normative affirmation of the legal principles; and managerial (in)competence based on the (non-) adoption and implementation of effective compliance systems. In relation to deterrence, and the threat of enforcement action, respondents generally were aware of the likelihood and high severity of enforcement action, though to an extent this reflected the focus of the study on post-infringement compliance, and the subsequent responses to questions of costs/gains and adoption of compliance elements did not appear to be consistent with the barometer of regulatory threat. More specifically, we considered business perceptions as to costs and gains of compliance and non-compliance with the Competition Act, and we also asked respondents to consider various enforcement scenarios and potential sanctions. Increasing the severity of sanctions clearly has an impact on levels of management concern, and although it has been suggested that punitive sanctions may be counter-productive, the study suggests that the level of fines imposed alone has not sufficiently motivated compliance efforts. However, this may be changing recently with the 'imposition' of higher fines, ${ }^{84}$ and there is also evidence that the message about the moral seriousness of

\footnotetext{
${ }^{83}$ See Winter and May, supra $\mathrm{n} 33$, regarding their threefold typology of compliance motivating factors:'calculative', 'normative' and 'social'.

${ }^{84}$ See for instance OFT press release 113/07, 1 August 2007, noting that BA is to pay a record $£ 121.5$ mill fine for collusion in relation to long-haul passenger fuel surcharges.
} 
the cartel offence has not been adequately communicated publicly, ${ }^{85}$ again supporting the need for further education campaigns by the OFT and by the wider political authorities to reinforce messages about the legitimacy of the competition rules, as highlighted by the National Audit Office.

Moreover, a focus on "perceptual deterrence" allows us to recognise that in addition to purely formal, enforcer-led sanctions, deterrence may extend to broader social and economic sanctions which may impact on compliance, a context in which third party stakeholders may play an important role in develop compliance culture by exercising a combination of businesses' calculative, social and normative motivations to comply. The results in this context were broadly similar to the Australian compliance study, although in respect of economic losses, there is more concern with shareholders than with customers in a UK context and a discernibly lower concern for loss of respect/esteem across the categories of third parties. This suggests that the OFT may have a bigger task in seeking to encourage and enhance the role of such third parties in promoting better compliance by those businesses in which they are stakeholders. Furthermore, given that

${ }^{85}$ C Parker, “The 'Compliance' Trap: The Moral Message in Responsive Regulatory Enforcement', (2006) 40 Law \& Society Review 591. See A Stephan, Survey of Public Attitudes to price-fixing and cartel enforcement in Britain, CCP Working Paper $07-12$, in which 73\% of respondents recognised the harmful effects of price-fixing but only $11 \%$ considered imprisonment to be appropriate, only $7 \%$ compared it to theft and $8 \%$ to fraud.

Interestingly, anecdotal comments from some of the respondents matched the typology of regulatee motivational posturing, involving blatantly antagonism to the regulatory regime, helplessness (disengagement), and offense at government intrusion, as set out by $\mathrm{V}$ Braithwaite, J Braithwaite, D Gibson, and T Makkai, in "Regulatory Styles, Motivational Postures and Nursing Home Compliance" (1994) 16 Law and Policy 363. 
respondents considered saved costs on lawyers/compliance professionals as the highest economic gains of breach, allied with the lack of concern about any loss of respect/esteem by those professionals associated with non-compliance, more work could be done to encourage compliance professionalism generally in this country. ${ }^{86}$

\footnotetext{
${ }^{86}$ See C Parker, "Compliance professionalism and regulatory community: The Australian Trade Practices regime" (1999) 26 Journal of Law \& Society 215.
} 